\title{
Evolutionary Lineages in Emballonura and Mosia Bats (Mammalia: Microchiroptera) from the Southwestern Pacific ${ }^{1}$
}

\author{
D. 7. Colgan ${ }^{2,3}$ and S. Sobeili ${ }^{2}$
}

\begin{abstract}
The microchiropteran bat family Emballonuridae is widely distributed in archipelagos of the southwestern Pacific, with especially strong representation of genera Emballonura and Mosia. DNA sequences from three segments of the mitochondrial genome were collected from four species of Emballonura and from M. nigrescens to investigate the relationship of genetic differentiation to archipelago biogeography. Specimens of each species formed monophyletic clades in maximum parsimony and Bayesian analyses. Mosia nigrescens was genetically distant to the other four species. The other four studied species formed a monophyletic clade composed of the pairs E. beccarii, E. serii and E. raffrayana, E. semicaudata. Clades within species were strongly concordant with geography, with only two counterexamples (E. semicaudata in Fiji and E. raffrayana in the Solomon Islands) to the general finding that each island's population of a species constitutes a monophyletic clade. Genetic results do not agree with current subspecific designations within $M$. nigrescens. Samples from Woodlark, Alcester, and Manus Islands are phylogenetically closer to Papuan mainland samples than to Solomon Islands and New Ireland samples supposedly belonging to the same subspecies. Results suggest that Emballonura can establish populations across wide water barriers but does so infrequently. The isolating effect of water barriers is exemplified by the substantial genetic distinctiveness of Solomon Islands and New Ireland populations of both $E$. raffrayana and M. nigrescens. Absence from New Britain of E. beccarii, E. raffrayana, and $E$. serii (all known from New Ireland) may also reflect effects of water barriers if not due to collecting artifacts.
\end{abstract}

Bats ARE THE MOST widespread of the endemic mammals of the western Pacific. $\mathrm{Na}$ tive marsupials and rodents are found in the Bismarck Archipelago, but the former do not extend east of this and the latter are not found beyond the Solomon Islands (Carvajal and Adler 2005). Ten genera of Megachiroptera are found in the region: Pteropus, Ptera-

${ }^{1}$ The Winifred Violet Scott Estate and the Australian Museum financially supported this research. Manuscript accepted 2 July 2007.

${ }^{2}$ Research Branch, Australian Museum, 6 College Street, Sydney, New South Wales 2010, Australia.

${ }^{3}$ Corresponding author: (phone: 612-9320-6030; fax: 612-9320-6020; e-mail: don.colgan@austmus.gov.au).

Pacific Science (2008), vol. 62, no. 2:219-232

(C) 2008 by University of Hawai'i Press

All rights reserved lopex, Macroglossus, Melonycteris, Notopteris, Nyctimene, Dobsonia, Rousettus, Syconycteris, and Mirimiri (Koopman 1984, Nowak 1994, Flannery 1995a,b, Bonaccorso 1998, Carvajal and Adler 2005, Helgen 2005). Five families of Microchiroptera (Emballonuridae, Hipposideridae, Rhinolophidae, Vespertilionidae, and Molossidae) have members with ranges extending east of Papua New Guinea (Nowak 1994, Flannery 1995b, Bonaccorso 1998, Carvajal and Adler 2005).

Achieving such wide oceanic distributions has probably been greatly assisted by flight. Geographic barriers may, however, have discernible effects on biogeographic structure within species despite this capacity (Heaney 2000). For example, close examination of phylogenetic lineages in relation to geography often suggests that the present-day distributions of flighted vertebrates within 
archipelagos are substantially influenced by the extent and persistence of water barriers between islands (Diamond et al. 1976, Mayr and Diamond 2001, Campbell et al. 2004, Carstens et al. 2004, Heaney et al. 2005, Roberts 2006). The effects of water barriers vary between species. Carstens et al. (2004) found marked differences in phylogeographic patterns in three microchiropteran species in the family Phyllostomidae in the Lesser Antilles. Heaney et al. (2005) found that differences in species' ecologies were important in determining how genetic differentiation between populations and variation within them respond to a common historical influence.

The existence and persistence of water barriers has been a principal determinant of the systematic status of birds in northern Melanesia (Diamond and Mayr 1976, Diamond et al. 1976, Mayr and Diamond 2001). The influence of water barriers on species' distributions has also been observed in megachiropteran blossom bats (genera Macroglossus, Syconycteris, and Melonycteris) in the region (Bonaccorso and $M c N a b$ 1997). In Melonycteris, there is a high correlation of genetic divergence and the historical extent of water barriers (Pulvers and Colgan 2007). The deepest phylogenetic divergence in the genus, which occurs between populations from the Bismarck Archipelago and the Solomon Islands, coincides with the widest water barrier within its range. The genetically closest pairs of populations are found on presentday islands that were connected by Pleistocene land bridges.

In this investigation we report a study of phylogeographic patterns in two genera of the microchiropteran family Emballonuridae that was undertaken to allow comparison with the results for Melonycteris and assess the generality of the influence of geographic history on bat phylogeography in the western Pacific. Emballonura was selected for the comparison because it is widely distributed in the region and has broad overlaps in species' ranges, in contrast to the strict allopatry of species found in Melonycteris. The overlaps suggest that at least some of the species have strong migratory capabilities, leading to the hypothesis that there would be reduced intra- specific phylogeographic structuring in the genus (compared with that observed in $\mathrm{Me}$ lonycteris). The monospecific genus Mosia (species nigrescens) was also included in the study because specimens were available from multiple archipelagos.

The family Emballonuridae has approximately 51 species in 13 genera (Simmons 2005). The family is widely distributed in tropical and subtropical regions. Nine of the genera are restricted to the Americas, and four are found in Africa, Asia, and the Pacific islands, extending east to Fiji and south to Australia. Taphozous, Saccolaimus, Emballonura, and Mosia are found in the southwestern $\mathrm{Pa}-$ cific region. Emballonura itself has 11 species, 10 recorded in Nowak (1994) and the recently described E. tiavato (Goodman et al. 2006). This species and E. atrata are found in Madagascar. The other species occur in Malaya and eastward. Emballonura beccarii, E. dianae, E. furax, and E. raffrayana are found in New Guinea (Flannery 1995a, Bonaccorso 1998). All of these species except $E$. furax occur in the Bismarck Archipelago. The New Ireland fauna also contains E. serii, a species related to $E$. furax but distinct (Flannery 1994). The New Britain emballonurid fauna is limited, with only $E$. dianae and $M$. nigrescens being recorded from the island (Bonaccorso 1998). Emballonura dianae, E. raffrayana, and $M$. nigrescens have been recorded from the Solomon Islands (Sanborn and Beecher 1947, Hill 1971, Flannery 1995b). Emballonura semicaudata is widely distributed in the islands of the western Pacific, ranging from Belau to Samoa (Koopman 1997). The conservation of this species is of particular concern because there have been dramatic or catastrophic reductions in population numbers in many parts of its range, including the Mariana Islands (Lemke 1986), Samoa (Grant et al. 1994, Tarburton 2002), and Fiji (Flannery 1995b), although it remained quite abundant in Belau as late as the mid-1990s (Wiles et al. 1997).

\section{MATERIALS AND METHODS}

The provenance of the 43 chiropteran samples used in this study is indicated in the Appendix and Figure 1. DNA was extracted 


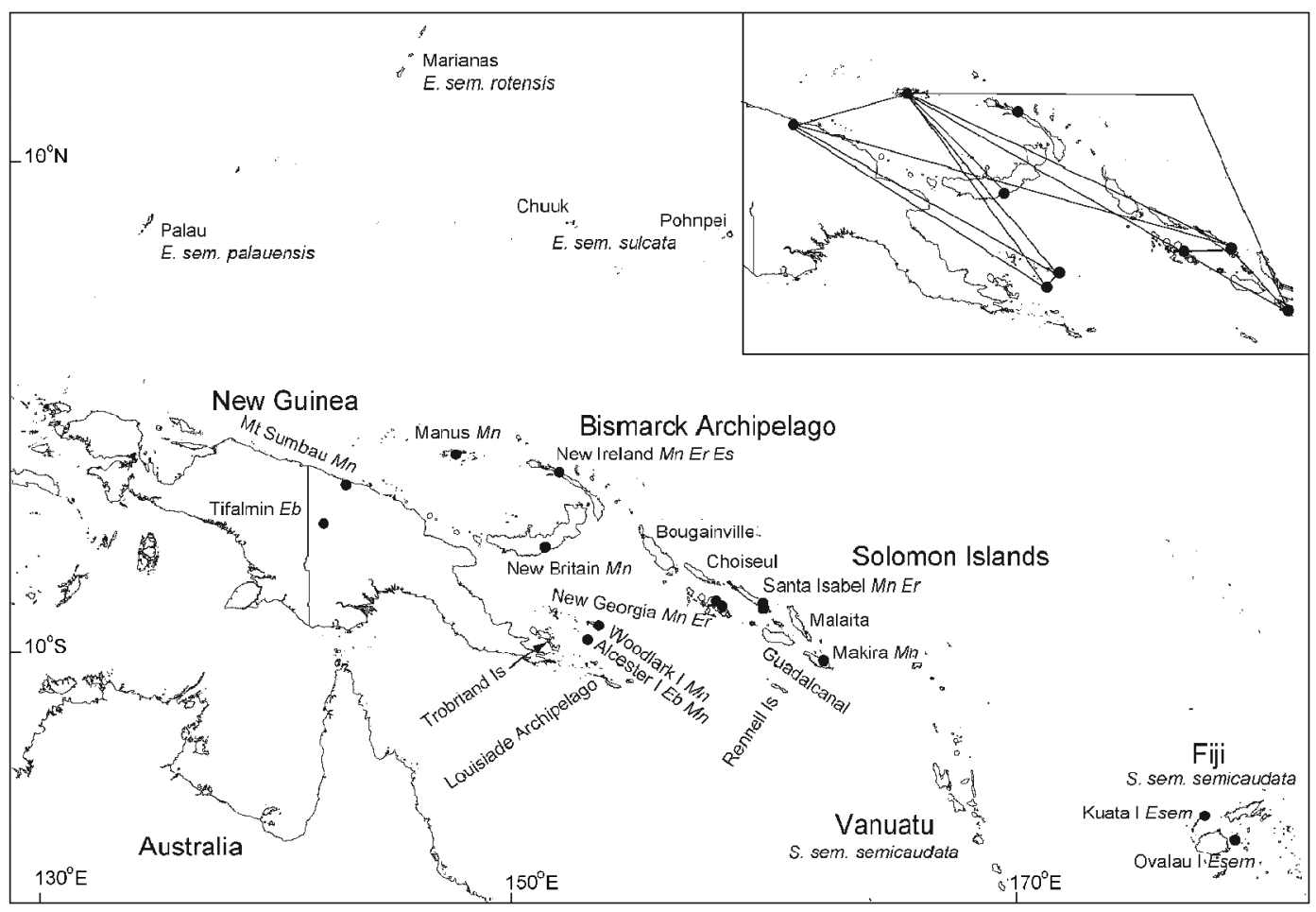

Figure 1. Map of the western Pacific showing sample locations. Localities are indicated by filled circles. Species sampled are specified by the following abbreviations: Emballonura beccarii, Eb; E. raffrayana, Er; E. semicaudata, Esem; E. serii, Es; and Mosia nigrescens, $M n$. Names of subspecies of E. semicaudata appear next to island or archipelago names. The inset shows linkages between the various populations of Mosia nigrescens. Lines connect those populations with Kimura 2 parameter average pairwise genetic distances less than 0.06 . The two localities in each of Santa Isabel and New Georgia were pooled for this illustration.

from these specimens by the CTAB method (Saghai-Maroof et al. 1984). Approximately $100 \mathrm{mg}$ of tissue was used and the extracted DNA was resuspended in $200 \mu \mathrm{l}$ of water. This stock DNA was diluted as required (generally 1 in 8 ) for amplification by the polymerase chain reaction (PCR).

Mitochondrial cytochrome $b$ (Cytb) and $12 \mathrm{~S}$ ribosomal RNA (12S rRNA) gene segments were amplified from Emballonura DNA by the Kocher et al. (1989) "universal" primers:

12SF: 5'-AAAAAGCTTCAAACTGGGATTAGATACCCCACTAT-3' and 12S R: 5'-TGACTGCAGAGGGTGACGGGCGGTGTGT-3'

CytBF: 5'-AAAAAGCTTCCATCCAACATCTCAGCATGATGAAA-3' ${ }^{\prime}$ and
CytBR: 5'-AAACTGCAGCCCCTCAGAATGATATTTGTCCTCA-3'

The universal primers of Folmer et al. (1994) were used to amplify part of cytochrome $c$ oxidase subunit I (COI):

1490F: 5'-GGTCAACAAATCATAAAGATATTGG-3' and 2198R: 5'-TAAACTTCAGGGTGACCAAAAAATCA-3'

PCR was performed using 0.5 to 1 unit of BIOTAQ (Bio-Line, London, United Kingdom) DNA polymerase, $0.05 \mathrm{mM}$ dNTPs, $3.5 \mathrm{mM} \mathrm{MgCl}_{2}, 12.5 \mathrm{pmol}$ of each primer, and $1 \mu \mathrm{l}$ of diluted DNA in a total reaction volume of $50 \mu \mathrm{l}$. Negative controls were included in each reaction array. Where necessary, annealing temperatures and $\mathrm{MgCl}_{2}$ 
concentration were varied to obtain PCR products suitable for DNA sequencing.

The standard cycling profile for Cytb and $12 \mathrm{~S}$ rRNA was as follows: $94^{\circ} \mathrm{C}$ for $3 \mathrm{~min}$, $51^{\circ} \mathrm{C}$ for $1 \mathrm{~min}, 72^{\circ} \mathrm{C}$ for $1 \mathrm{~min}$ for one cycle; $94^{\circ} \mathrm{C}$ for $30 \mathrm{sec}, 51^{\circ} \mathrm{C}$ for $1 \mathrm{~min}, 72^{\circ} \mathrm{C}$ for $1 \mathrm{~min}$ for 32 cycles; and $72^{\circ} \mathrm{C}$ for $3 \mathrm{~min}$ for the final cycle. The same conditions were standard for COI, except that the annealing temperature was reduced to $43^{\circ} \mathrm{C}$.

PCR products were purified manually with a magnet using Ampure beads (Agencourt, Beverly, Massachusetts) following the manufacturer's protocol. Except as specified in the Appendix products were sequenced in both directions. Sequencing reactions were cleaned by ethanol precipitation and run on an automatic capillary sequencer (General Electric Megabace) using the ET (General Electric) sequencing chemistry according to the manufacturer's protocols except that sequencing buffer ( $1 \mathrm{M}$ tris- $\mathrm{HCl}, 1 \mathrm{M} \mathrm{MgCl}, \mathrm{pH} 9.0)$ $(4 \mu \mathrm{l})$ was used and the amount of ET reduced to $4 \mu \mathrm{l}$ in a final reaction of $20 \mu \mathrm{l}$.

Sequences were edited using Sequencher version 4.1.2 (Gene Codes Corporation, Ann Arbor, Michigan). Cytochrome $b$ and/or 12S rRNA sequences were obtained from GenBank for other Emballonuridae and, as more distant outgroups, a species of Nycteridae and three Vespertilionidae (details given in Appendix). Sequence alignment was performed using the default parameters in CLUSTALX (Thompson et al. 1997). Indels inferred by the alignment were not modified.

PAUP v4b10 (Swofford 2003) was used to conduct maximum parsimony (MP) analysis, assuming default settings. Heuristic searches were conducted with 1,000 replicates of random taxon addition sequence keeping no more than 50 trees of length greater than 200 steps (to avoid filling the tree buffer in a single replicate). Gaps were treated as unknown. Bootstrap analyses were conducted with 1,000 pseudosampling replicates, each with 50 random taxon addition replicates keeping no more than 50 trees of length greater than 200 steps. Analyses were also conducted for the individual genes, with 200 replicates with random taxon addition keeping no more than 200 trees of length greater than 200 steps. Bootstrap analyses of individual segments used 200 resampling replicates each with 20 random addition replicates keeping no more than 200 trees of length greater than 200 steps.

Bayesian (BY) analyses were conducted with the program MrBayes 3.1.2 (Huelsenbeck and Ronquist 2001) using a character partition giving a total of seven sections $(12 \mathrm{~S}$ rRNA and each codon position within Cytb and COI). Likelihood parameters were estimated separately during the run for each section in the partition using the "unlink" command in MrBayes. Base frequencies were estimated, as were the rates of all substitution types. A discrete gamma distribution was assumed for rate variation between nucleotide positions, and the shape parameter of this distribution was estimated. Trees were sampled every 100 steps along a 2,000,000step Markov Chain. Four differentially heated chains were included in each of the two simultaneous runs. To allow for convergence to an area of stable likelihood (burn-in), sufficient steps from the chain were discarded so that all included trees had likelihoods no worse than $0.2 \%$ poorer than those of the final trees in the simulation. The majority rule consensus tree for calculating posterior probabilities was based on the inclusion of all trees after the cutoff in both runs. Posterior probabilities were multiplied by 100 to give the node support levels (PPS) reported here.

Average pairwise nucleotide distances between groups of sequences were calculated using Mega version 3.0 (Kumar et al. 2004) using the Tamura-Nei distance assuming a gamma distribution with a shape parameter $(\alpha)$ of 1 for specifying substitution rate variation over sites. Missing bases were removed by pairwise deletion. Standard deviations were estimated by bootstrap resampling using 500 replicates.

\section{RESULTS}

The GenBank Accession Numbers for sequences collected for this study are detailed in the Appendix. The nucleotide composition of the taxa in the dataset was not significantly 
heterogeneous for any gene segment, whether or not species from genera other than Emballonura or Mosia were included $(P>.999$ for all five tests-only Emballonura or Mosia species were available for COI). In the 393 aligned bases for $12 \mathrm{~S}$ rRNA, 214 positions were invariant when all species were included (267 considering only Emballonura and Mosia); 43 (21) were variable but parsimony uninformative; and 136 (105) were both variable and parsimony informative. Four indels in the $12 \mathrm{~S}$ rRNA sequence were due to the presence of an extra base in one or more nonemballonurid species. One other indel was due to the presence of three extra bases in one nonemballonurid (with one other nonemballonurid having one extra base). Within Emballonuridae, several apparent deletions mostly between one and three bases were observed. One four-base deletion, shared by the Peropteryx species, was inferred. Only one indel was inferred in comparisons among the Emballonura and Mosia sequences. This was an apparent loss of three bases in Mosia because these were represented in all other species examined (including non-emballonurids). The CCT motif for these bases in E. beccarii was observed in all Emballonuridae except $E$. semicaudata (with CTT), E. serii, and E. raffrayana (both CCC). In the 359 aligned positions for Cytb, 197 were invariant when all sequences were included (197 when attention was restricted to Emballonura and Mosia); 19 (13) were variable but parsimony uninformative; and 143 (131) were parsimony informative. There were 556 aligned bases for COI (only Emballonura and Mosia sequences were available), of which 333 were constant, 34 variable but parsimony uninformative, and 189 parsimony informative. The Cytb and COI sequences were translated to amino acid sequences to check for anomalous stop codons. None was inferred.

The strict consensus of the 24,450 maximum parsimony trees, each of 1,649 steps, found for the combined data is shown in Figure 2. The majority rule consensus topology of the trees sampled from the MetropolisCoupled, Monte Carlo Markov Chain Bayesian analysis is shown in Figure 3. The first 100,000 steps in the chain from the first run (i.e., 1,000 sampled trees) and the first 200,000 steps in the second chain $(2,000$ trees) were discarded as burn-in to allow for convergence. There was some bootstrap (64\%) and substantial posterior probability support $(\mathrm{PPS}=94)$ for monophyly of the western Pacific Emballonura. Within this grouping of four species there was strong support for the sister pairing of, first, E. beccarii and E. serii and, second, E. semicaudata and E. raffrayana.

Individual bat specimens are grouped with their nominal species in both MP and BY. There were no examples where haplotypes from within a single island were found in widely divergent lineages. Indeed only two examples were observed where groups of individuals from different islands were not sorted into monophyletic clades. For E. semicaudata, the specimens from two areas of Fiji were not resolved in MP (Figure 2). The New Georgia and Santa Isabel specimens of E. raffrayana were intermingled in MP (Figure 2) and not resolved in BY (Figure 3).

Averages and standard deviations of the pairwise genetic distances of $12 \mathrm{~S}$ rRNA sequence between populations are shown in Table 1. Emballonura raffrayana was separated into two groups that may be related to distinct subspecies (see Discussion). The genetic distance in $12 \mathrm{~S}$ rRNA separating these two groups, respectively the populations from the Solomon Islands and New Ireland, was $0.035 \pm 0.010$ (Table 1). For comparison, the average pairwise distances between members of the two groups formed by the initial division in $M$. nigrescens (Figure 2) was $0.070 \pm 0.012$. The corresponding distances for the two sets of samples in each species were $0.075 \pm 0.018$ for E. raffrayana Cytb and $0.181 \pm 0.049$ for $M$. nigrescens. For COI the values were $0.093 \pm 0.015$ and $0.114 \pm 0.015$.

Kimura 2-parameter net average pairwise distances were calculated using MEGA for comparing divergence between Santa Isabel and New Georgia Islands in Emballonura and Mosia with the results in Melonycteris (Pulvers and Colgan 2007). The average distance for Cytb in E. raffrayana was $0.001 \pm 0.001$ compared with $0.060 \pm 0.014$ between the two 


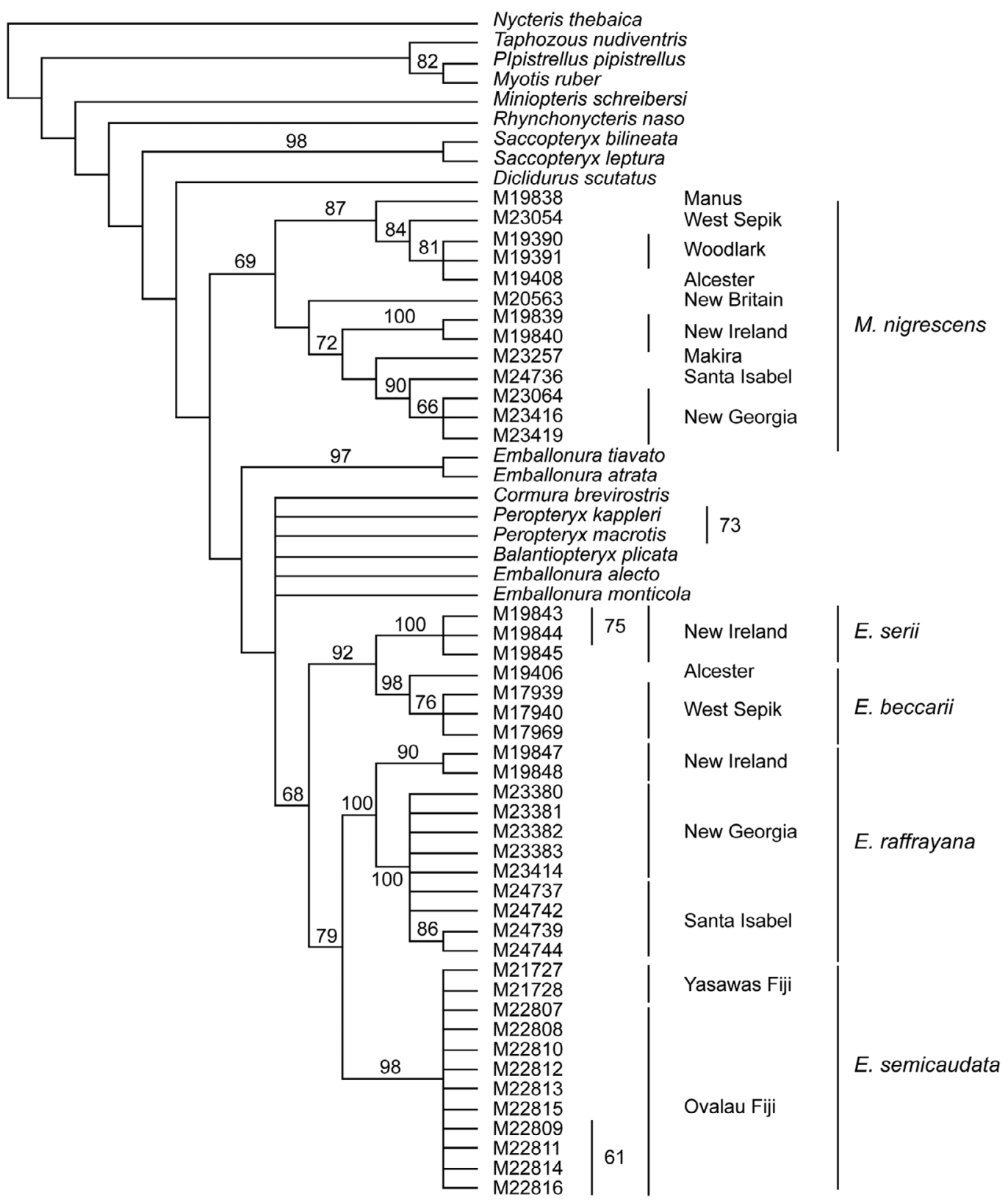

FIgURE 2. The strict consensus topology of maximum parsimony trees for the combined data. Numbers written after " $\mathrm{M}$ " in specimen designations are Australian Museum registration numbers. The generic name Emballonura is abbreviated to $E$. and the name Mosia to $M$. for southwestern Pacific specimens. Maximum parsimony bootstrap support percentages over 60 are written near the relevant nodes or beside linking bars at the right of the specimen designation. 


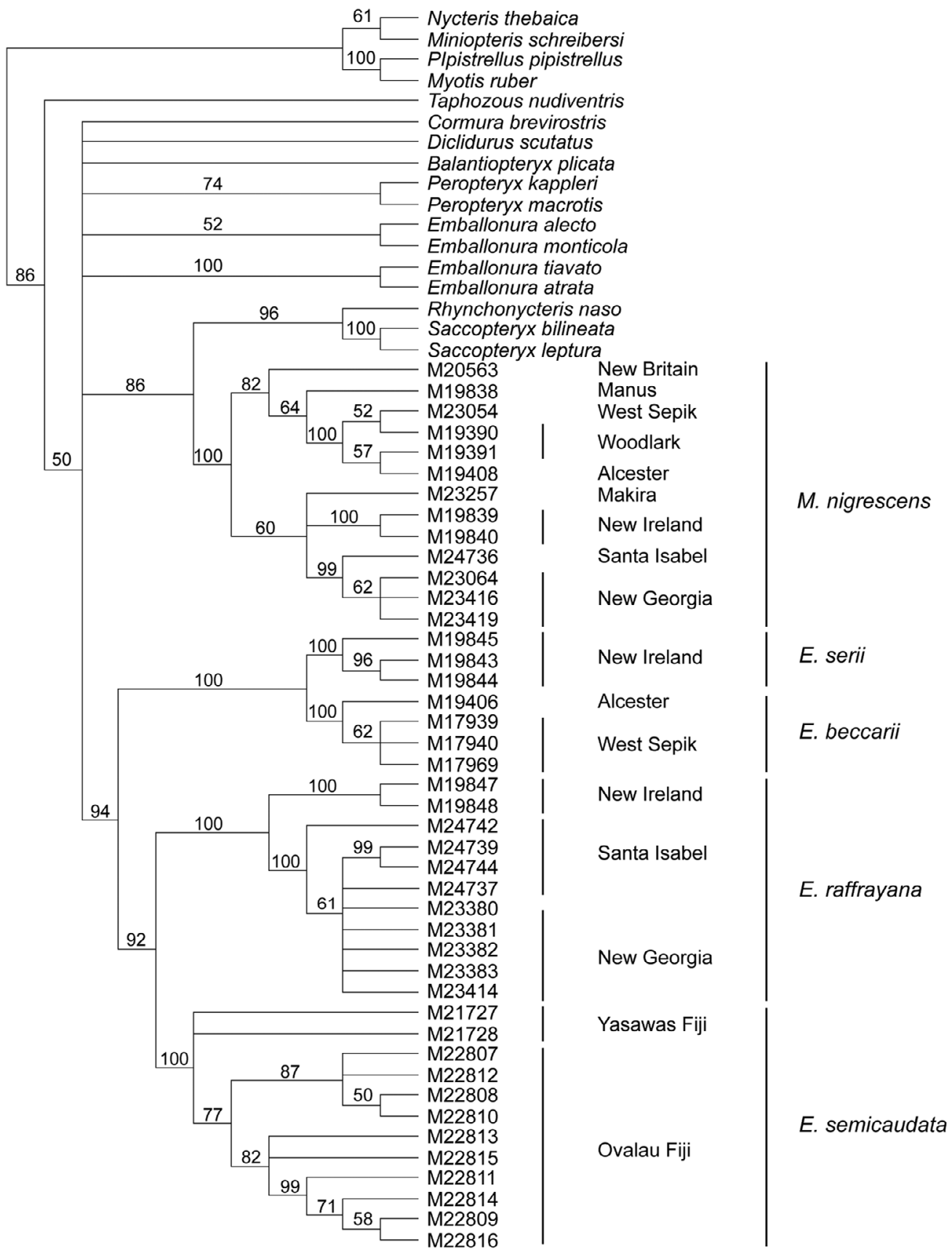

Figure 3. Majority rule consensus of the 17,000 trees sampled during the Metropolis-Coupled, Monte Carlo Markov Chain simulation for the combined data. Numbers written after " $M$ " in specimen designations are Australian Museum registration numbers. The generic name Emballonura is abbreviated to $E$. and the name Mosia to $M$. for southwestern Pacific specimens. Posterior probability support levels over 50 are written near the relevant nodes. 
TABLE 1

Genetic Distances between Species Based on the 12S rRNA Sequences

\begin{tabular}{|c|c|c|c|c|c|c|c|c|c|}
\hline Species & M. $n$. & E. $b$. & E. $s$. & E. $r$. NI & E. $r$. SI & E. sem. & E. a./E. $t$. & R. $n$. & T. $n$. \\
\hline M. nigrescens & & 0.019 & 0.031 & 0.030 & 0.034 & 0.031 & 0.027 & 0.025 & 0.036 \\
\hline E. beccarii & 0.125 & & 0.024 & 0.026 & 0.028 & 0.029 & 0.029 & 0.033 & 0.032 \\
\hline E. serii & 0.205 & 0.164 & & 0.026 & 0.022 & 0.027 & 0.033 & 0.038 & 0.036 \\
\hline E. raffrayana NI & 0.184 & 0.171 & 0.135 & & 0.010 & 0.021 & 0.038 & 0.029 & 0.041 \\
\hline E. raffrayana SI & 0.218 & 0.196 & 0.119 & 0.035 & $\mathrm{P}^{-}$ & 0.021 & 0.037 & 0.035 & 0.043 \\
\hline E. semicaudata & 0.187 & 0.189 & 0.133 & 0.113 & 0.108 & & 0.039 & 0.036 & 0.043 \\
\hline E. atrata/tiavato & 0.169 & 0.196 & 0.190 & 0.209 & 0.219 & 0.215 & & 0.040 & 0.056 \\
\hline Rbynchonycteris naso & 0.174 & 0.225 & 0.245 & 0.167 & 0.226 & 0.226 & 0.219 & & 0.035 \\
\hline Taphozous nudiventris & 0.227 & 0.234 & 0.225 & 0.230 & 0.265 & 0.254 & 0.297 & 0.221 & \\
\hline
\end{tabular}

Note: The figures in cells below the diagonal are average pairwise Tamura-Nei distances between the samples from the specified localities calculated using MEGA 3.1 (Kumar et al. 2004). Figures above the diagonal are the standard deviations of the averages. Emballonura raffrayana is split into two groups: NI indicates the specimens from New Ireland and SI indicates specimens from the Solomon Islands. In the first column, Emballonura is abbreviated E. and Mosia as $M$. In the header row, the species' names excepting E. semicaudatus are abbreviated to the initial letters of their binomials.

species of Melonycteris on the islands ( $M$. fardoulisi on New Georgia and M. woodfordi on Santa Isabel). This calculation could not be made for $M$. nigrescens because no data were available from Santa Isabel. For COI, the average was $0.009 \pm 0.003$ for E. raffrayana and $0.008 \pm 0.005$ for $M$. nigrescens compared with $0.055 \pm 0.010$ in Melonycteris (Pulvers and Colgan 2007).

\section{DISCUSSION}

Genetic Lineages in Relation to Systematics and Phylogeny

Analyses of mitochondrial DNA sequences suggest that the species $M$. nigrescens, $E$. beccarii, E. raffrayana, E. serii, and E. semicaudata represent distinct monophyletic lineages corresponding to current taxonomic understanding. The results were less concordant with subspecies designations. Two subspecies of $M$. nigrescens have been recognized in the region (Laurie and Hill 1954). These are M. $n$. solomonis in the Solomon Islands, Bismarck Archipelago, Admiralty Islands, and Woodlark Island and $M$. $n$. papuana on the mainland of New Guinea (Flannery 1995a,b). Koopman (1982) considered that further investigation is needed to clarify the status of the populations from the East Papuan islands. Using the genetic data, samples from Alcester and Woodlark Islands were related not to the
Solomon Islands and New Ireland M. nigrescens but rather to the mainland specimen from the West Sepik Province. The monophyletic clade including these individuals had bootstrap support of $84 \%$ and PPS of $100 \%$. The individual from Manus in the Admiralty Islands was the sister to this clade in BY (PPS $=64 \%$ ) and MP (with a bootstrap support of $87 \%$ ). The position of the $M$. nigrescens specimen from New Britain was not resolved in these analyses. The BY analysis gave some support $(\mathrm{PPS}=82 \%)$ to its inclusion in the Alcester/Woodlark/Manus/ mainland clade rather than with specimens from the Solomon Islands and New Ireland.

There are two subspecies of $E$. raffrayana in the region: E. r. raffrayana in New Guinea and nearby islands and E. r. cor in the Solomon Islands (Flannery 1995a,b). Specimens from the Tabar Islands east of New Ireland have also been referred to the subspecies $E$. $r$. cor (Koopman 1979), raising questions about the status of the New Ireland population. The individuals of $E$. raffrayana collected by Smith and Hood (1981) on New Ireland were not referred to a subspecies by them but were described as notably larger in size than $E$. raffrayana cor. The genetic distances between the populations are not high, but strong bootstrap and posterior support for the reciprocal monophyly of bats from the Solomon Islands and New Ireland was found 
here. These results suggest that the bats from these two areas may belong to distinct subspecies.

Differences between populations within any of the other three species studied in multiple localities were not large enough to suggest the probable existence of subspecific differentiation. Samples were available from only one of the two subspecies of E. beccarii in the region, E. b. meeki from eastern New Guinea (Flannery 1995a) and the Trobriand Islands (Flannery 1995b). No subspecies are recognized in E. serii. There are four recognized subspecies of E. semicaudata (Koopman 1997). These are E. s. palauensis from Palau; E. s. rotensis from the Marianas; E. s. sulcata from Chuuk and Pohnpei in the Caroline Islands; and E. s. semicaudata from Samoa, Tonga, Fiji, Rotuma, and Vanuatu. Samples were studied from the last, easternmost, of these taxa but only within the Fiji archipelago where no substantial differentiation was observed.

Robbins and Sarich (1988) used electrophoretic data to identify three main clades in the Emballonuridae. The first comprised all eight studied New World genera (Cyttarops was not studied), the second was Taphozous plus Saccolaimus, and the third was Emballonura (including nigrescens) plus Coleura. The results presented here differ substantially from this hypothesis, particularly in the division of the New World genera into multiple lineages, each associated with Old World genera. Such differences should, however, be regarded as only suggestive until more sequence data, including genes other than $12 \mathrm{~S}$ rRNA, become available from additional African and American species.

The analyses presented here do not challenge the removal of the species nigrescens from the genus Emballonura to Mosia by Griffiths et al. (1991). In all MP trees for the combined data, $M$. nigrescens is the sister group to a large clade including all Emballonura species and three other genera (although this clade does not have bootstrap support). In the BY analysis most genera are unresolved. Mosia nigrescens is, however, included in a clade with Rhynchonycteris and Saccopteryx that has $86 \%$ posterior probability support.
The sister pairs of E. beccarii and E. serii and E. raffrayana and E. semicaudata found within southwestern Pacific Emballonuridae contrast somewhat with the intrageneric strict consensus topology of Griffiths et al. (1991). Considering taxa common to both studies, that topology shows E. raffrayana and $E$. beccarii as linked by a synapomorphy (the presence of posteriorly recessed basisphenoid pits) lacking from E. semicaudata (Griffiths et al. 1991). Emballonura serii was not described until 1994 (Flannery 1994) so was not considered in Griffiths et al. (1991).

\section{Geographic Distribution of Genetic Variation} within Western Pacific Emballonuridae

Fossil data indicate that evolutionary divergences in Emballonuridae date from at least the early mid-Tertiary (Barghoorn 1977). Molecular clock calculations made by Teeling et al. (2005) suggest that Emballonura atrata and Rhynchonycteris naso diverged about 30 $\mathrm{Ma}$ (estimated range 25-35) and E. atrata and Taphozous nudiventris about $42 \mathrm{Ma}$ (range 37-47). These divergences are so ancient that the influence of the southwestern Pacific's tectonic history on evolution within the family may have been substantial. There have been major changes in the relative position of the island arcs of the Southwest Pacific and Southeast Asia in the last 5 to 20 million yr (Hall 1998, 2002, Pettersen et al. 1999). However, the complexity of this history and the overlap of ranges make it difficult to interpret phylogeographically the contemporary distributions of Emballonura at the species level. Phylogeographic patterns are, however, clearer within species.

Each of the distinct monophyletic specieslevel clades in the studied western Pacific Emballonuridae was itself composed of clades that are strongly concordant with geographical location. For example, E. raffrayana has distinct Solomon Islands and New Ireland clades. Mosia nigrescens specimens from the central Solomon Islands (New Georgia and Santa Isabel) form the sister group to the southern Solomon Islands specimen from Makira, with bats from New Ireland and then New Britain being the next most closely 
related. Only in E. semicaudata from the Fijian archipelago and E. raffrayana from the Solomon Islands do the bats of a species' population on a single island not form a monophyletic clade.

The overlapping distribution of species in Emballonura does contrast with the situation in Melonycteris in which species are allopatric. However, with a few exceptions, there is an underlying similarity in the phylogeographic pattern of assortment of lineages within species to islands. One exception is the low level of differentiation between populations from Santa Isabel and New Georgia within species of both Emballlonura and Mosia, whereas Melonycteris from those islands are separated into distinct lineages (Pulvers and Colgan 2007). The results indicate relatively recent divergence between the Santa Isabel and New Georgia populations of both E. raffrayana and $M$. nigrescens. In the absence of land bridges, this suggests that these bats can cross water barriers more readily than does Melonycteris, in which gene flow between these islands is reduced to very low levels (Pulvers and Colgan 2007). In both species, however, the distance between the Solomon Islands and New Ireland has been too great for continued substantial gene flow.

The Makira specimen of $M$. nigrescens is the most distinct of the Solomon Islands samples. This is similar to the pattern in Melonycteris where the population of $M$. fardoulisi fardoulisi from that island is the sister group to all congeners in the archipelago (Pulvers and Colgan 2007). The birds of Makira are also more differentiated from those on other islands than the avifauna of any of the major Solomon Islands (Mayr and Diamond 2001). The explanations of this differentiation offered by Mayr and Diamond were that Makira receives some species as immigrants from eastern archipelagos such as Vanuatu; that central islands in the Solomon Islands receive migrants from multiple directions, whereas Makira does not; and that the orientation of the long axis of the island to the long axis of other islands presents a small target for potential immigrants. The second and third of these may also be part of the explanation for the bat data, if the populations on
Makira are not frequent participants in gene exchange within the Solomon Islands. As discussed next, the genetic data indicate that immigration/gene flow between Fiji and the Solomon Islands Emballonura has been minimal for a long period.

Emballonura raffrayana from New Ireland and the Solomon Islands is the sister group to E. semicaudata from Fiji in these analyses, but they are genetically distant. The average Tamura-Nei distance between the species is greater than 0.10 (about one third the distance between E. atrata/E. tiavato and Taphozous nudiventris that are calculated to have diverged between 37 and $47 \mathrm{Ma}$ [Teeling et al. 2005]). This comparison suggests that, unless there has been an extraordinarily rapid rate of substitution in the E. raffrayanal E. semicaudata lineages, their separation occurred at least several million years ago. Considerable genetic divergence has also been observed between Fiji and Solomon populations of another microchiropteran, Chaerophon jobensis (Ingleby and Colgan 2003). A neighbor joining tree based on allozymic frequencies indicated a very close relationship between the populations from Fiji and $\mathrm{Va}-$ nuatu (C. jobensis bregullae). Chaerophon j. solomonis from the Solomon Islands is genetically quite distant, having two loci at which no alleles are shared with bats from the southeastern archipelagoes.

The seeming poverty of the New Britain emballonurid fauna is anomalous for bats with a high migratory capacity. Only $M$. nigrescens and $E$. dianae have been recorded from New Britain (Bonaccorso 1998; F. Bonaccorso, pers. comm.). Mosia nigrescens is also the sole Emballonura-like species known from the islands between New Britain and the Papuan mainland (Koopman 1979, Bonaccorso 1998). The failure to find other species on New Britain may possibly be a collecting artifact, because the fauna of the Bismarck Archipelago was little known before 1979 (Smith and Hood 1981). Expeditions to the island have not been numerous, but multiple collections have been made (Flannery 1995b, Bonaccorso 1998; F. Bonaccorso, pers. comm.), reducing the strength of this argument. Hall (1998) noted that parts of New 
Britain have been emergent since the late Miocene $(10 \mathrm{Ma})$. If this were the case, then lack of time for colonization would not explain the island's low species numbers. It may be that the island has been colonized by more Emballonura species in the past, with their absence today explained by unrecorded extinctions.

\section{ACKNOWLEDGMENTS}

We thank Sandy Ingleby for checking specimen information, Frank Bonaccorso for information about species distributions, Chris Lee for collecting some sequences, Gareth Carter of the GIS Unit of the Australian Museum for preparation of the digital maps on which Figure 1 is based, and Rebecca Johnson for running sequencing reactions on the automatic sequencer. We are grateful for the comments of two anonymous reviewers on an early draft of the manuscript. We are especially thankful for the collecting efforts of Tim Flannery and his coworkers.

\section{Literature Cited}

Barghoorn, S. F. 1977. New material of Vespertiliavus Schlosser (Mammalia, Chiroptera) and suggested relationships of emballonurid genera based on cranial morphology. Am. Mus. Novit. 2618.

Bonaccorso, F. 1998. Bats of Papua New Guinea. Conservation International, Washington, D.C.

Bonaccorso, F., and B. K. McNab. 1997. Plasticity of energetics in blossom bats (Pteropodidae): Impact on distribution. J. Mammal. 78:1073-1088.

Campbell, P., C. J. Schneider, A. M. Adnan, A. Zubaid, and T. H. Kunz. 2004. Phylogeny and phylogeography of Old World fruit bats in the Cynopterus brachyotis complex. Mol. Phylogenet. Evol. 33:764781.

Carstens, B. S., J. Sullivan, L. M. Davalos, P. A. Larsen, and S. C. Pedersen. 2004. Exploring population genetic structure in three species of Lesser Antillean bats. Mol. Ecol. 13:2557-2566.

Carvajal, A., and G. H. Adler. 2005. Biogeog- raphy of mammals on tropical Pacific islands. J. Biogeogr. 32:1561-1569.

Diamond, J. M., and E. Mayr. 1976. Speciesarea relation for birds of the Solomon Archipelago. Proc. Natl. Acad. Sci. U.S.A. 73:262-266.

Diamond, J. M., M. E. Gilpin, and E. Mayr. 1976. Species-distance relation for birds of the Solomon Archipelago, and the paradox of the great speciators. Proc. Natl. Acad. Sci. U.S.A. 73:2160-2164.

Flannery, T. F. 1994. Systematic revision of Emballonura furax Thomas, 1911 and $E$. dianae Hill, 1956 (Chiroptera: Emballonuridae), with description of new species and subspecies. Mammalia 58:601-612.

- 1995a. Mammals of New Guinea. Rev. ed. Australian Museum/Reed Books, Chatswood, Australia.

. 1995b. Mammals of the South-West Pacific and Moluccan Islands. Australian Museum/Reed Books, Chatswood, Australia.

Folmer, O., M. Black, W. Hoeh, R. Lutz, and R. Vrijenhoek. 1994. DNA primers for amplification of mitochondrial cytochrome c oxidase subunit I from diverse metazoan invertebrates Mol. Mar. Biol. Biotechnol. 3:294-299.

Goodman, S. M., S. G. Cardiff, J. Ranivo, A. L. Russell, and A. D. Yoder. 2006. A new species of Emballonura (Chiroptera: Emballonuridae) from the dry regions of Madagascar. Am. Mus. Novit. 3538.

Grant, G. S., S. A. Banack, and P. Trail. 1994. Decline of the sheath-tailed bat Emballonura semicaudata (Chiroptera: Emballonuridae) on American Samoa. Micronesica 27:133-137.

Griffiths, T. F., K. F. Koopman, and A. Starrett. 1991. The systematic relationship of Emballonura nigrescens to other species of Emballonura and to Coleura (Chiroptera: Emballonuridae). Am. Mus. Novit. 2996.

Hall, R. 1998. The plate tectonics of cenozoic SE Asia and the distribution of land and sea. Pages 99-132 in R. Hall and J. D. Holloway, eds. Biogeography and geological evolution of SE Asia. Backhuys Publishers, Leiden.

- 2002. Cenozoic geologic and plate 
tectonic evolution of SE Asia and the SW Pacific: Computer-based reconstructions, model and animations. J. Asian Earth Sci. 20:353-431.

Heaney, L. R. 2000. Dynamic disequilibrium: A long-term, large-scale perspective on the equilibrium model of island biogeography. Global Ecol. Biogeogr. 9:59-74.

Heaney, L. R., J. S. Walsh Jr., and A. T. Peterson. 2005. The roles of geological history and colonisation abilities in genetic differentiation between mammalian populations in the Philippine archipelago. J. Biogeogr. 32:229-247.

Helgen, K. M. 2005. Systematics of the Pacific monkey-faced bats (Chiroptera: Pteropodidae), with a new species of Pteralopex and a new Fijian genus. Syst. Biodivers. 3:433-453.

Hill, J. E. 1971. Bats from the Solomon Islands. J. Nat. Hist. 5:573-581.

Huelsenbeck, J. P., and F. R. Ronquist. 2001. MrBayes: Bayesian inference of phylogeny. Bioinformatics 17:754-755.

Ingleby, S., and D. J. Colgan. 2003. Electrophoretic studies of the systematic and biogeographic relationships of Fijian bats. Aust. Mammal. 25:13-30.

Kocher, T. D., W. K. Thomas, A. Meyer, S. V. Edwards, S. Pääbo, F. X. Villablanca, and A. C. Wilson. 1989. Dynamics of mitochondrial DNA evolution in animals: Amplification and sequencing with conserved primers. Proc. Natl. Acad. Sci. U.S.A. 86:6196-6200.

Koopman, K. F. 1979. Zoogeography of mammals from islands off the northeastern coast of New Guinea. Am. Mus. Novit. 2690.

1982. Results of the Archbold Expeditions. No. 109. Bats from eastern Papua and the East Papuan islands. Am. Mus. Novit. 2747.

. 1984. Bats. Pages 145-186 in S. Anderson and J. K. Jones, eds. Orders and families of recent mammals of the world. John Wiley and Sons, New York.

. 1997. The subspecies of Emballonura semicaudata (Chiroptera: Emballonuridae). J. Mammal. 78:358-360.

Kumar, S., K. Tamura, and M. Nei. 2004.
MEGA3: Integrated software for molecular evolutionary genetics analysis and sequence alignment. Briefings Bioinformat. 5:150-163.

Laurie, E. M. D., and J. E. Hill. 1954. List of land mammals of New Guinea, Celebes and the adjacent islands, 1758-1952. British Museum (Natural History), London.

Lemke, T. O. 1986. Distribution and status of the sheath-tailed bat (Emballonura semicaudata) in the Mariana Islands. J. Mammal. 67:734-746.

Mayr, E., and J. Diamond. 2001. The birds of northern Melanesia. Oxford University Press, Oxford.

Nowak, R. M. 1994. Walker's bats of the world. The Johns Hopkins University Press, Baltimore.

Pettersen, M. G., T. Babbs, C. R. Neal, J. J. Mahoney, A. D. Saunders, R. A. Duncan, D. Tolia, R. Magu, C. Qopoto, H. Mahoa, and D. Natogga. 1999. Geologicaltectonic framework of Solomon Islands, SW Pacific: Crustal accretion and growth within an intra-oceanic setting. Tectonophysics 301:35-60.

Pulvers, J. N., and D. J. Colgan. 2007. Molecular phylogeography of the fruit bat genus Melonycteris in northern Melanesia. J. Biogeogr. 34:713-723.

Robbins, L. W., and V. M. Sarich. 1988. Evolutionary relationships in the family Emballonuridae. J. Mammal. 69:1-13.

Roberts, T. E. 2006. Multiple levels of allopatric divergence in the endemic Philippine fruit bat Haplonycteris fischeri (Pteropodidae). Biol. J. Linn. Soc. 88:329-349.

Saghai-Maroof, M. A., K. M. Soliman, R. A. Jorgensen, and R. W. Allard. 1984. Ribosomal DNA spacer length variation in barley: Mendelian inheritance, chromosomal location and population dynamics. Proc. Natl. Acad. Sci. U.S.A. 81:8018-8021.

Sanborn, C. C., and W. J. Beecher. 1947. Bats from the Solomon Islands. J. Mammal. 28:387-391.

Simmons, N. B. 2005. Emballonuridae. Pages 81-91 in D. E. Wilson and D. M. Reeder, eds. Mammal species of the world. 5 th ed. Vol. 1, Johns Hopkins University Press, Baltimore. 
Smith, J. D., and C. S. Hood. 1981. Preliminary notes on bats from the Bismarck Archipelago (Mammalia: Chiroptera). Sci. New Guinea 8:81-121.

Swofford, D. L. 2003. PAUP: Phylogenetic analysis using parsimony. Version 4.0. Laboratory of Molecular Systematics, Smithsonian Institution, Washington, D.C.

Tarburton, M. K. 2002. Demise of the Polynesian sheath-tailed bat Emballonura semicaudata in Samoa. Micronesica 34:105108.

Teeling, E. C., M. S. Springer, O. Madsen, P. Bates, S. J. O'Brien, and W. J. Murphy.
2005. A molecular phylogeny for bats illuminates biogeography and the fossil record. Science (Washington, D.C.) 307:580-584.

Thompson, J. D., T. J. Gibson, F. Plewniak, F. Jeanmougin, and D. G. Higgins. 1997. The CLUSTALX windows interface: Flexible strategies for multiple sequence alignment aided by quality analysis tools. Nucleic Acids Res. 25:4876-4882.

Wiles, G. J., J. Engbring, and D. Otobed. 1997. Abundance, biology, and human exploitation of bats in the Palau Islands. J. Zool. 241:203-227.

\section{Appendix}

Specimen Provenance and GenBank Accession Numbers for the Compiled Data (Species are from the genus Emballonura unless otherwise specified. Australian Museum Mammalogy registration numbers are given in the second column. The number in the third column refers to the list of provenance locations. Papua New Guinea is

abbreviated as PNG in the list. An asterisk beside an accession number indicates that the sequence was determined in only one direction. Data were not available for the species and gene fragment combination where cells in the

Accession Number columns are blank. All but one sequence, AY044802, from Australian Museum specimens, were collected for this paper.)

\begin{tabular}{|c|c|c|c|c|c|}
\hline Species & Registration & Location & 12S rRNA & Cytb & COI \\
\hline \multirow[t]{4}{*}{ E. beccarii Peters \& Doria } & M17939 & 1 & - & - & EF635571 \\
\hline & M17940 & 1 & EF635503* & - & EF635572* \\
\hline & M17969 & 1 & EF635504* & EF635537 & EF635573* \\
\hline & M19406 & 2 & EF635502 & - & EF635570 \\
\hline \multirow[t]{11}{*}{ E. raffrayana Dobson } & M19847 & 3 & EF635513* & EF635545* & EF635580 \\
\hline & M19848 & 3 & EF635514 & EF635546* & EF635581 \\
\hline & M24737 & 4 & EF635534 & EF635566 & - \\
\hline & M24739 & 4 & EF635535 & EF635567 & - \\
\hline & M24742 & 4 & - & EF635568 & EF635594 \\
\hline & M24744 & 4 & EF635536 & EF635569 & - \\
\hline & M23380 & 5 & EF635526 & EF635560 & EF635588* \\
\hline & M23381 & 5 & EF635527 & EF635561* & EF635589* \\
\hline & M23382 & 5 & EF635528* & EF635562* & - \\
\hline & M23383 & 5 & EF635529 & EF635563 & - \\
\hline & M23414 & 5 & EF635530 & EF635564 & EF635590* \\
\hline \multirow[t]{12}{*}{ E. semicaudata (Peale) } & M21727 & 6 & AY044802 & - & - \\
\hline & M21728 & 6 & EF635515 & - & - \\
\hline & M22807 & 7 & EF635516 & EF635548 & EF635583 \\
\hline & M22808 & 7 & EF635517 & EF635549 & EF635584 \\
\hline & M22809 & 7 & EF635518 & EF635550 & - \\
\hline & M22810 & 7 & - & EF635551 & EF635585* \\
\hline & M22811 & 7 & EF635519 & EF635552 & EF635586* \\
\hline & M22812 & 7 & EF635520 & EF635553* & - \\
\hline & M22813 & 8 & EF635521 & EF635554 & - \\
\hline & M22814 & 8 & - & EF635555 & - \\
\hline & M22815 & 8 & - & EF635556 & - \\
\hline & M22816 & 8 & EF635522 & EF635557 & - \\
\hline \multirow[t]{3}{*}{ E. serii Flannery } & M19843 & 9 & EF635519 & EF635543* & - \\
\hline & M19844 & 9 & EF635520 & EF635544 & EF635578* \\
\hline & M19845 & 9 & - & - & EF635579* \\
\hline
\end{tabular}


Appendix (continued)

\begin{tabular}{|c|c|c|c|c|c|}
\hline Species & Registration & Location & 12S rRNA & Cytb & COI \\
\hline \multirow{13}{*}{ Mosia nigrescens Gray } & M23054 & 10 & EF635523* & EF635558* & - \\
\hline & M19408 & 11 & EF635507* & EF635540* & - \\
\hline & M19390 & 12 & EF635505* & EF635538* & - \\
\hline & M19391 & 12 & EF635506 & EF635539* & EF635574* \\
\hline & M19838 & 13 & EF635508 & - & EF635575* \\
\hline & M20563 & 14 & - & EF635547* & EF635582 \\
\hline & M19839 & 15 & EF635509 & EF635541* & EF635576* \\
\hline & M19840 & 15 & EF635510 & EF635542* & EF635577* \\
\hline & M23257 & 16 & EF635525 & EF635559 & - \\
\hline & M23416 & 17 & EF635531 & - & EF635591* \\
\hline & M23064 & 17 & EF635524 & - & EF635587* \\
\hline & M23419 & 17 & EF635532* & EF635565 & EF635592 \\
\hline & M24736 & 18 & EF635533 & - & EF635593 \\
\hline \multicolumn{6}{|l|}{ GenBank Data } \\
\hline \multicolumn{3}{|c|}{ Emballonura atrata Peters } & AF203773 & DQ178260 & - \\
\hline \multicolumn{3}{|c|}{ Emballonura alecto (Eydoux \& Gervais) } & - & AY426101 & - \\
\hline \multicolumn{3}{|c|}{ Emballonura monticola Temminck } & - & AY057946 & - \\
\hline \multicolumn{3}{|c|}{ Emballonura tiavato Goodman et al. } & - & DQ178283 & - \\
\hline \multicolumn{3}{|c|}{ Balantiopteryx plicata Peters } & AY395847 & - & - \\
\hline \multicolumn{3}{|c|}{ Cormura brevirostris (Wagner) } & AY395848 & - & - \\
\hline \multicolumn{3}{|c|}{ Diclidurus scutatus Peters } & AY141036 & - & - \\
\hline \multicolumn{3}{|c|}{ Peropteryx kappleri Peters } & AY395849 & - & - \\
\hline \multicolumn{3}{|c|}{ Peropteryx macrotis (Wagner) } & AY395850 & - & - \\
\hline \multicolumn{3}{|c|}{ Rhynchonycteris naso (Wied-Neuwied) } & AY395851 & - & - \\
\hline \multicolumn{3}{|c|}{ Saccopteryx bilineata Temminck } & AF263213 & - & - \\
\hline \multicolumn{3}{|c|}{ Saccopteryx leptura (Schreiber) } & AY395852 & - & - \\
\hline \multicolumn{3}{|c|}{ Taphozous nudiventris Cretzschmar } & AY395853 & - & - \\
\hline \multicolumn{3}{|c|}{ Nycteris thebaica E. Geoffroy } & AY012140 & AF044653 & - \\
\hline \multicolumn{3}{|c|}{ Miniopteris schreibersi (Kuhl) } & AY395865 & AY208138 & - \\
\hline \multicolumn{3}{|c|}{ Pipistrellus pipistrellus (Schreiber) } & AF326105 & AY582290 & - \\
\hline \multicolumn{3}{|c|}{ Myotis ruber E. Geoffroy } & AY495506 & AF376867 & - \\
\hline
\end{tabular}

Locations

1: Tifalmin, West Sepik Province, PNG: $5^{\circ} 7^{\prime} \mathrm{S}, 141^{\circ} 25^{\prime} \mathrm{E}$

2: Sea cave near village, Alcester Island, Milne Bay Province, PNG: $9^{\circ} 33^{\prime} \mathrm{S}, 152^{\circ} 26^{\prime} \mathrm{E}$

3: Balof Cave, near Medina, New Ireland, PNG

4: Cave near Ghove Village, Santa Isabel, Solomon Islands: $8^{\circ} 21^{\prime} \mathrm{S}, 159^{\circ} 32^{\prime} \mathrm{E}$

5: Mondomondo Island, Marovo Lagoon, New Georgia, Solomon Islands: $8^{\circ} 16^{\prime} \mathrm{S}, 157^{\circ} 49^{\prime} \mathrm{E}$

6: Kuata Island, Yasawas, Fiji: $17^{\circ} 22^{\prime} \mathrm{S}, 177^{\circ} 08^{\prime} \mathrm{E}$

7: Cave approx. $2 \mathrm{~km} \mathrm{~S}$ of Lovoni Village, Ovalau Island, Fiji: $17^{\circ} 43^{\prime} \mathrm{S}, 178^{\circ} 48^{\prime} \mathrm{E}$

8: Cave a few kilometers NE of Lovoni Village, Ovalau Island, Fiji: $17^{\circ} 43^{\prime} \mathrm{S}, 178^{\circ} 49^{\prime} \mathrm{E}$

9: Matapara Cave near Medina, New Ireland, PNG: $2^{\circ} 55^{\prime} \mathrm{S}, 121^{\circ} 53^{\prime} \mathrm{E}$

10: Foot of Mt. Sumbau near Sibilanga, West Sepik Province, PNG: $3^{\circ} 32^{\prime} \mathrm{S}, 142^{\circ} 31^{\prime} \mathrm{E}$

11: Sea cave, Alcester Island, Milne Bay Province, PNG: $9^{\circ} 33^{\prime} \mathrm{S}, 152^{\circ} 26^{\prime} \mathrm{E}$

12: Guasopa, Woodlark Island, Milne Bay Province, PNG: $9^{\circ} 13^{\prime} \mathrm{S}, 152^{\circ} 56^{\prime} \mathrm{E}$

13: Polomou DPI Station, south-central Manus, PNG: $5^{\circ} 33^{\prime} \mathrm{S}, 154^{\circ} 36^{\prime} \mathrm{E}$

14: Melei near Fulleborn, West New Britain, PNG: 6 $3^{\prime}$ S, $156^{\circ} 40^{\prime} \mathrm{E}$

15: Medina, New Ireland, PNG: $2^{\circ} 54^{\prime} \mathrm{S}, 151^{\circ} 22^{\prime} \mathrm{E}$

16: Manigharaghara Village, Makira Island, Solomon Islands: $10^{\circ} 31^{\prime} \mathrm{S}, 161^{\circ} 55^{\prime} \mathrm{E}$

17: Tamaneke Village, Marovo Lagoon, New Georgia, Solomon Islands: $8^{\circ} 19^{\prime} \mathrm{S}, 157^{\circ} 49^{\prime} \mathrm{E}$

18: San Jorge Island, Santa Isabel, Kaolo, Solomon Islands: $8^{\circ} 23^{\prime} \mathrm{S}, 159^{\circ} 33^{\prime} \mathrm{E}$ 